\title{
Skill Analysis through Inquiry Learning Model
}

\author{
Fitria Wulandari \\ Fakultas Keguruan dan Ilmu Pendidikan \\ Universitas Muhammadiyah Sidoarjo \\ Sidoarjo, Indonesia \\ wulandarifitria17@gmail.com
}

\author{
Fika Megawati \\ Fakultas Keguruan dan Ilmu Pendidikan \\ Universitas Muhammadiyah Sidoarjo \\ Sidoarjo, Indonesia
}

\begin{abstract}
Lack of scientific attitude tends to be a problem in learning activities. It potentially hinders the effectiveness of knowledge transfer in the classroom activities. To solve the problem, inquiry learning model is proposed due to its benefits. In this study, the model was applied in the science class to identify how the instructional process run with the model. The research used descriptive research method in which the data analysis used descriptive statistics. The results showed that students learning for indicators of skills to observe, predict, and conclude almost entirely on the good category. Skill to communicate reaches the highest point. Regarding the strengths of this model, it is recommended that inquiry learning can be a solution for educators and expected to be implemented in all study program.
\end{abstract}

Keywords-inquiry; students; learning

\section{INTRODUCTION}

Skills can be interpreted as the ability to use mind, reason and action effectively and efficiently to achieve a certain result. While the process can be defined as the complex skills used by scientists in conducting scientific research. From this we can see that the process of skills is important things that must be trained early on especially school education because it can empower the mind and creativity of students [1]. In addition, science process skills of intellectual skills is owned and used by scientists in researching natural phenomena [2]. Another understanding mentions science process skills are all necessary skills to acquire, develop, and apply the concepts, laws, and theories of science, both in the form of mental skills, physical skills as well as social skills[3]. This definition gives the sense that the process of skills not only in the form of physical skills in the form of the action, but can also be mental and social skills that can be applied in scientific activities[4].

Based on the pre-liminary observation, it is found that the students in one class of primary education study program were less able to work scientifically and lack in understanding of science subject and its application. It is apparent from the low results of test. The average value was 64.7. this leads the the researcher to describe the profile of the students' science process skills by creating a draft of learning that can ancourage their process skills in science. The selected learning models for this study is through inquiry model.
Inquiry learning is a learning activity that involves the most throughout the student's ability to find and investigate things (objects, people, or events) in a systematic, critical, logical, analytical so that they can formulate its own discovery confidently [5][6].

\section{METHODS}

This study is a descriptive research, where data analysis used was descriptive statistics, namely the presentation of research results through the form of tables, graphs, figures, calculation of the mean, the dissemination of data and percentage. This research includes experimental research because science process skills in observing the student enact treatment. Type of experiment in this study is the PreExperimental Design (non-design) with the One-Shot Case Study. The population were thirty students oh the fourth semester. The sampling technique that is used is saturated. That's where all the population used for samples.

Instrument in this study is the Student Worksheet with assessment rubric. The student worksheet contains a series of tasks and questions that each of its components refer to the process of science skills. The following steps are sequence of data analysis techniques.

a. Give the raw score for each student well in performance the performance as well as on the results of performance assessment rubrics guide appropriate

b. Add value accumulated on each student for each of the indicators of the science process skills.

c. Change the raw score for each of the indicators of the science process skills into a percentage with this formula

percentage value for each indicator $=\frac{\sum \text { raw score }}{\Sigma \text { maximum score }} \times 100 \%$

d. Count average score on each aspect of process skills

e. Specify the categories of science process skills of each student based on the scale of skill categories. TABLE 1. TABLE OF PROCESS SKILL CATEGORY

\begin{tabular}{|c|c|}
\hline Score (\%) & Skill Categogy \\
\hline $0.00-20.00$ & Very poor \\
\hline $20.00-39.99$ & Poor \\
\hline $40.00-59.99$ & Enough \\
\hline $60.00-79.99$ & Good \\
\hline $80.00-100.00$ & Very good \\
\hline
\end{tabular}

f. The next step is to interpret the distribution of skills in the process of science students based on the scale in table 2 . 
TABLE 2. SCIENCE PROCESS SKILL DISSEMINATION

\begin{tabular}{|c|c|}
\hline Percentage (\%) & Dissemination \\
\hline 0.00 & Nobody \\
\hline $0.01-25.00$ & Less \\
\hline $25.01-49.99$ & Nearly half \\
\hline 50.00 & Half \\
\hline $50.01-75.00$ & Mostly \\
\hline $75.01-99.99$ & Almost all \\
\hline 100.00 & All \\
\hline
\end{tabular}

\section{FINDINGS AND DISCUSSION}

Science process skills to be measured in this study include the skills of observing, predicting, communicating, and concluding. The following is a profile of the science process skills of the students.

\section{A. Performance assessment test results at the first meeting}

On the first praticum activity, the skill of inferring has the largest percentage $(60 \%)$, the second one is observing skill $(54.85 \%)$. For the skills to communicate and to predict, they reach the third and fourth position with percentage $52.42 \%$ $49.166 \%$. The figure 1 is science process skills of students at the first meeting.

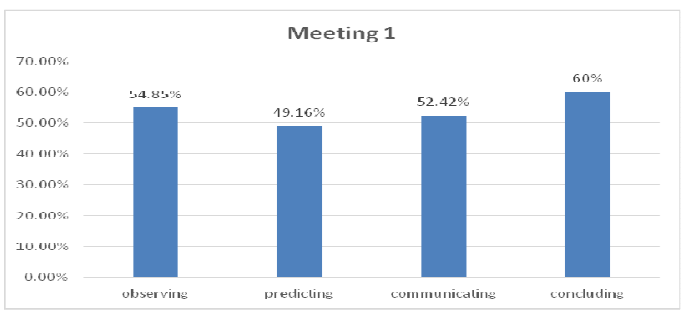

Fig. 1. Science process skills in first meeting

B. Performance assessment test results at the second meeting

On the second praticum, the skill of inferring has the largest percentage of value of $69.16 \%$, skills in predictding get the second rank with percentage of $68.33 \%$. To observe the skills of communicating sequential ranked third and fourth with the percentage of $58.68 \%$ and $58.33 \%$. The figure 2 is science process skills of students at the second meeting.

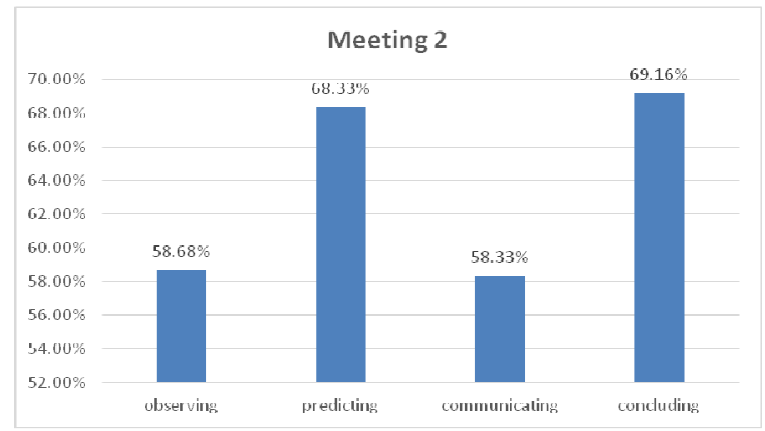

Fig. 2. Science process skills in second meeting

For each science process skill dissemination, it can be interpreted from table $3,4,5$, and 6 .

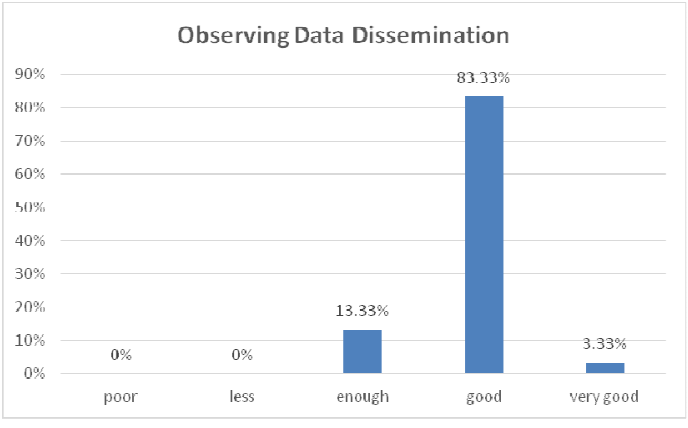

Fig. 3. Observing skill dissemination

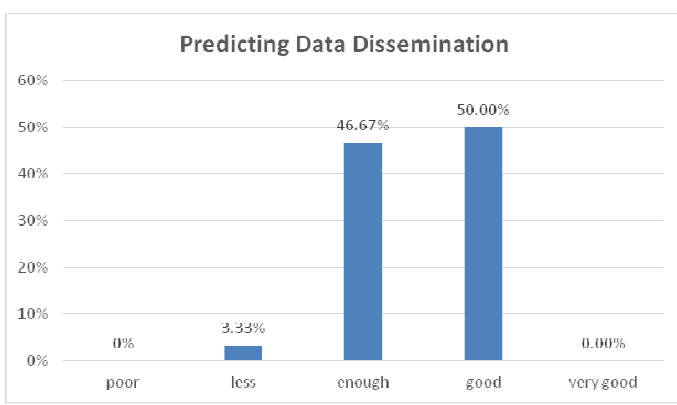

Fig. 4. Predicting skill dissemination

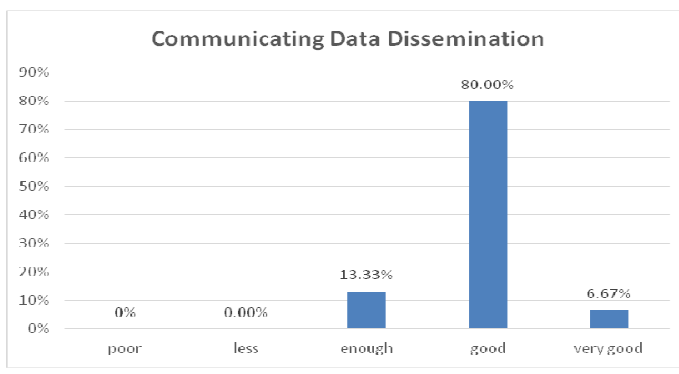

Fig. 5. Communicating skill dissemination

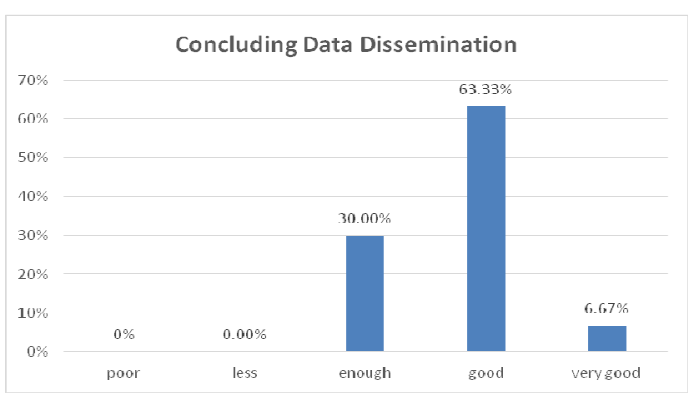

Fig. 6. Concluding skill dissemination

Based on the results of each skill dissemination, the science process skills of the students through the inquiry learning model show positive contribution, for the indicators of skill observed almost entirely on the good category. Half od the response in predicting skills achieve good category. Skill to communicate almost entirely on the good category. Finally, the skill of inferring or concluding dominantly achieve good 
category. Performance assessment is a form of assessment appropriate to assess students' science process skills. Thus, the inquiry learning and performance assessment test can be one alternative learning and learning assessment, particularly science subjects.

The information focuses on each aspect of science process skills is discussed as follows.

\section{Observing}

Observation is one of the significant skills. Observing is different from watching. When students observed, they were asked to use the five senses to achieve maximum result [7]. The increase occurring in this area indicates that there was students' seriousness in the classroom activities.

2. $\quad$ Predicting

Prediction skill needs carefulness . However, during the implementation, some students did not write their prediction appropriately. Half wrote some statements, while the others wrote nothing. This means that to predict, the students need the accurate examples which lead them to practice in their context. In other words, predictive learning need to be trained [8].

3. Communicating

Communicating skill in this study covers discussing the result of experiment, comparing data with other groups', and the ability to explain the result of practicum. When the students were able to communicate well, the discussion session became more alive and interactive. Knowledge and motivation aspect also influence the students to participate [9]. Although not all of the students were actively state their ideas, the teacher could identify their competence through the way they delivered their presentation and answered questions.

4. Concluding

From the observation, the students had made their conclusion although some of them could not give the expected results. Three things that affect the conclusion drawing are confidence, intellectual abiliy, and personality traits[9].

\section{CONCLUSION}

This study strengthens that inquiry learning model encourages the students active in learning. It also makes the knowledge can be easily interpreted. Another important case is the development of creativity, scientific attitude, and process skills is always triggered [10]. Teacher guidance also becomes the consideration to run the inquiry model implementation well [11]. This study indicates that all educators including teachers and student teachers need to understand more abour inquiry learning to gain more benefits in learning process [12].

\section{ACKNOWLEDGEMENT}

The authors send their gratitude to Universitas Muhammadiyah Sidoarjo for finance support and facilities during paper accomplishment. Besides, they thank the reviewers for constructive comments and insightful ideas to shape this work into a better writing.

\section{REFERENCES}

[1] P. Devi, Pendekatan-Pendekatan dalam Pembelajaran IPA. Bandung: PPPPTK IPA, 2016.

[2] U. Samatowa, Pembelajaran IPA Di Sekolah Dasar. Jakarta: PT. Indeks, 2010.

[3] R. et al, Materi Pembelajaran IPA SD. Jakarta: Universitas Terbuka.

[4] S. Manlove, A. W. Lazonder, and T. de Jong, "Collaborative versus individual use of regulative software scaffolds during scientific inquiry learning," Interact. Learn. Environ., vol. 17, no. 2, pp. 105117, Jun. 2009.

[5] J. et al, "Teori dan Implementasi Model-Model Pembelajaran Inovatif," 2011.

[6] T. Bell, D. Urhahne, S. Schanze, and R. Ploetzner, "Collaborative Inquiry Learning: Models, tools, and challenges," Int. J. Sci. Educ., vol. 32, no. 3, pp. 349-377, Feb. 2010.

[7] J. S. Johnston, "What Does the Skill of Observation Look Like in Young Children?," Int. J. Sci. Educ., vol. 31, no. 18, pp. 2511-2525, Dec. 2009.

[8] H. Rabagliati, C. Gambi, and M. J. Pickering, "Learning to predict or predicting to learn?," Lang. Cogn. Neurosci., vol. 31, no. 1, pp. 94-105, Jan. 2016.

[9] B. H. Spitzberg, "Communication competence as knowledge, skill, and impression," Commun. Educ., vol. 32, no. 3, pp. 323-329, Jul. 1983.

[10] J. A. Jocz, J. Zhai, and A. L. Tan, "Inquiry Learning in the Singaporean Context: Factors affecting student interest in school science," Int. J. Sci. Educ., vol. 36, no. 15, pp. 2596-2618, Oct. 2014.

[11] F. E. Lombard and D. K. Schneider, "Good student questions in inquiry learning," J. Biol. Educ., vol. 47, no. 3, pp. 166-174, Sep. 2013.

[12] W.-M. W. So, M.-H. M. Cheng, S.-C. Kong, and N.-Y. F. Ching, "Views of primary science teachers towards the use of online resources to support the implementation of inquiry learning," Educ. 3-13, vol. 42, no. 4, pp. 386-401, Jul. 2014. 